\title{
Assessing Good-practice Frameworks for the Development of Sustainable Energy Communities in Europe: Lessons from Denmark and Ireland
}

\author{
Eimear Heaslip ${ }^{* 1}$, Gabriel J. Costello ${ }^{2}$, John Lohan ${ }^{3}$ \\ ${ }^{1}$ Department of Mechanical and Industrial Engineering, Galway-Mayo Institute of Technology, Dublin \\ Road, Galway, Ireland \\ e-mail: Eimear.Heaslip@ research.gmit.ie \\ ${ }^{2}$ Department of Mechanical and Industrial Engineering, Galway-Mayo Institute of Technology, Dublin \\ Road, Galway, Ireland \\ e-mail: GabrielJ.Costello@gmit.ie \\ ${ }^{3}$ Department of Mechanical and Industrial Engineering, Galway-Mayo Institute of Technology, Dublin \\ Road, Galway, Ireland \\ e-mail: John.Lohan@gmit.ie
}

Cite as: Heaslip, E., Costello, G. J., Lohan, J., Assessing Good-practice Frameworks for the Development of Sustainable Energy Communities in Europe: Lessons from Denmark and Ireland, J. sustain. dev. energy water environ. syst., 4(3), pp 307-319, 2016, DOI: http://dx.doi.org/10.13044/j.sdewes.2016.04.0024

\begin{abstract}
This paper presents findings from initial fieldwork studies of sustainable energy community development methodologies in two islands in Denmark and one rural village in Ireland. The main goals of this study were to determine the enablers and barriers to their successful development and to assess the successful elements of these previously implemented sustainable energy community development methodologies. The study involved extensive semi-structured interviews with the managers of the sustainable energy community projects and comprehensive site visits of each project. The evidence presented in this paper indicates that social barriers are interconnected and often reinforce each other. This article suggests that a comprehensive understanding of how barriers can be transformed into enablers supports the successful development of sustainable energy communities at local level in Europe. The findings in this research indicate that although each of the sustainable energy communities studied did not have any specific implementation framework developed for their projects, many of the successful tools and methodologies used across all communities were similar. The significant contribution of this work is the illumination of key factors influencing the successful development of sustainable energy communities in Ireland and Europe.
\end{abstract}

\section{KEYWORDS}

Sustainable energy communities, Community participation, Public acceptance, Renewable energy in Denmark and Ireland.

\section{INTRODUCTION}

This research sought to investigate existing frameworks for the motivation, structuring and implementation of Sustainable Energy Communities ${ }^{\dagger}$ (SECs). The research consisted of the analysis of two relatively successful SECs in Denmark and one in Ireland in order to determine how their methodologies could be redeployed in other

\footnotetext{
* Corresponding author

$\dagger$ The author recognises that many different types of communities exist, that communities are not homogeneous and that there can be multiple communities of practice within a spatial community [1]. The term "community" is used here to designate a spatial community or a community of place
} 
communities throughout Europe. There are several guidelines, frameworks and networks available to inform the development of sustainable energy communities including: the Sustainable Energy Authority of Ireland's (SEAI) "Guidelines for a Sustainable Energy Community" [2], the "CONCERTO Guide to a Sustainable built Environment" [3], the Local Governments for Sustainability (ICLEI) [4] and the Covenant of Mayors [5]. As defined in several of these documents, a SEC is a community that draws a significant portion of its energy from sustainable energy sources. Building on this, the SEAI defines a SEC as a community "in which everyone comes together to create a sustainable energy system" [2]. There are a number of existing SECs in Europe including: the Isle of Eigg in Scotland, the Marstal community in Aerø Island in Denmark, Samsø Island in Denmark [6], the region of Güssing in Austria [7] and Cloughjordan eco-village in Ireland [8] (Figure 1).

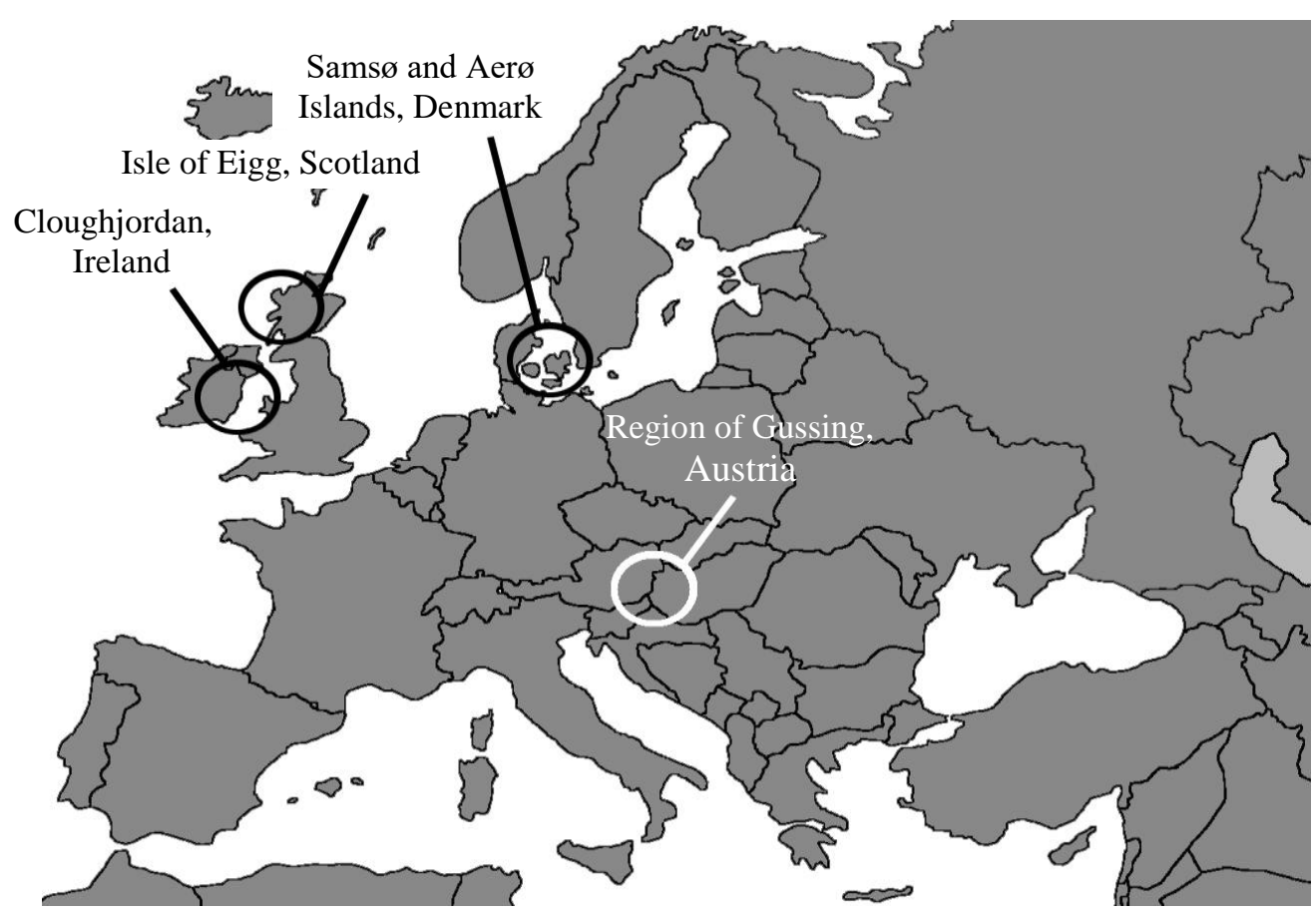

Figure 1. Location map of some existing Sustainable Energy Communities

Several academics argue that the successful development of SECs is rooted in community acceptance and societal integration of sustainable energy technologies. While discussing models and incentives for community ownership of renewable energy projects, Walker [9] describes several barriers to the successful development of community energy. These barriers include legal conditions, economic and technical viability of projects and finally the need for extensive liaison with communities. Furthermore, Blake's [10] discussion of the value-action gap highlights several barriers to action including, but not limited to: individuality, responsibility, practicality and the involvement of public and expert knowledge in the development process. Büscher and Sumpf's [11] work also highlights the importance of fostering trust between stakeholders in the development process in order to achieve a more collaborative community energy project. This paper leverages previous studies analysing public perceptions and understandings of community renewable energy projects $[12,13]$ and builds on these bodies of research in the context of sustainable communities and the social aspect of energy integration and acceptance. The paper is structured as follows; firstly the context to the research and sustainable energy and communities is described. Next the 
methodology used for this initial fieldwork is outlined. Following this the findings are detailed including a discussion in relation to literature studied. Finally conclusions and recommendations for future work are proposed.

\section{ENERGY POLICY IN DENMARK AND IRELAND}

The European Parliament's "Energy 2020" set Europe wide sustainable energy targets including: a $20 \%$ reduction in greenhouse gases, a $20 \%$ share of renewable energy and a $20 \%$ reduction in primary energy consumption by 2020 [14]. Although many countries in Europe are actively trying to achieve these targets, Denmark is leading the way in the race to increase their share of energy obtained from renewables. Historically, Denmark has been a pioneer in wind energy due to the co-operative nature of its wind energy provision. Denmark can provide useful lessons on the importance of financial incentives and ownership structures for community renewable energy ownership as well as the social, cultural and political aspects of SEC development. Mendonça et al. [15] describe how SEC development in Denmark was originally driven from the "bottom-up", beginning with enthusiasts influencing the political process. This forced the government to provide incentives to encourage development of the renewable energy sector [14]. As a result, a combined "top-down" and "bottom-up" approach (which is still favoured by the EU today [3]) was created. In an attempt to continue their past successes, in 2012, the Danish government created very ambitious energy targets with the aim of reducing greenhouse gas emissions by $40 \%$ by 2020 . Furthermore Denmark aims to have all their electricity and heating supply completely based on renewable energy by 2035 and have all energy consumption, including the transport sector, based on renewables by 2050 [16].

Meanwhile, in 2009, the Irish government released it's first "National Renewable Energy Action Plan" [17] which described Ireland's commitment to reach $40 \%$ renewable electricity and $12 \%$ renewable heating by 2020 . In an effort to contribute towards achieving these targets the SEAI released their "Guidelines for a Sustainable Energy Community" in 2010 [2]. These guidelines implied that a move from a fossil fuel based economy to an economy sustained by renewable energy sources is a societal rather than a technological issue. In order to attend to this issue the SEAI set up the SEC Programme [18]. The vision of the SEC programme was to stimulate a national move towards sustainable energy practice through the creation of 6 exemplar SECs by 2015. However, Ireland has considerably more work to undertake in order to achieve its 2020 targets. Electricity generated from renewable energy reached $20.9 \%$ of gross electricity consumption in 2013 [19] highlighting how Ireland is facing a considerable challenge to meet its energy targets by 2020. In 2014, Ireland imported $85 \%$ of its energy requirements (ibid.) leaving the country vulnerable to fluctuations and instabilities in the price of energy resources. Furthermore, recent renewable energy development guidelines released by the National Economic and Social Council (NESC) in Ireland have outlined the increasing need for meaningful consultation in the development process of sustainable energy projects [20] to ensure more successful outcomes. Responding to these events, Irish policymakers released the government White Paper; "Ireland's Transition to a Low Carbon Energy Future" in 2015 [21]. More consideration was afforded to the role of communities in Ireland's energy policy than in preceding white papers [22] on Ireland's sustainable energy future. The complexities of community engagement with the energy issue have been earmarked for considerable focus in the coming years [21]. In order to delve into these issues further, the following sections discuss the current state of SECs in Europe. Following this the barriers and enablers outlined in literature are presented and discussed. 


\section{SUSTAINABLE ENERGY AND COMMUNITIES}

Several studies describe the importance of the technological integration of sustainable energy systems [23-25] but there is a lack of knowledge on the enablers and barriers associated with the social issues surrounding the community acceptance of these technologies. As previously described, many academics have highlighted the importance of community engagement in community renewable energy projects. Walker and Devine-Wright's [26] discussion of community energy highlights how the varied mix of interpretations around community energy create a complex social dimension to the concept. However little research is available on suitable techniques and frameworks for engaging with communities in order to increase their acceptance of renewable energy projects.

The drivers behind the development of SECs can often have the most influence over a community's acceptance of the project. This can regularly create resentment towards the project early in the development process. According to Jørgensen et al. [6] the driving force behind the success of the Samsø project was the community's need for economic recovery (due to high unemployment rates). Although the reduction of greenhouse gases is often cited by policy makers as drivers for SECs, this is not generally the case at grass-roots level $[10,11]$. It is important for SEC developers to discuss with communities the positives of energy autonomy and energy security [27] and ensure that the aims of SECs are aligned with the needs and wants of the communities involved. The early identification of the type of community involved will affect the ease of development of a SEC and can be useful information when designing a development strategy. Schweizer-Ries [28] identifies two types of communities: the "conscious community" (who still have to implement the realization) and the "realizing community" (who have a lack of public consciousness) stating that the methods used for the successful development of each SEC may be quite different. Determining the best method for dealing with different types of communities can lead to differing approaches during the early stages of a project.

In their work Rogers et al. [12] outline the barriers to the acceptance of SEC projects and reasons for members of the community's reluctance to participate and support these projects in their areas. These include technical and economic factors and chiefly public opposition to wind farms. Furthermore research indicates that willingness to get involved in projects is often much lower than willingness to support it, possibly due to the "value-action gap" [10]. Value action gaps are the difference between what people say and what people do and arise because of individuals' attitudes and the social and institutional context for change (ibid.). Studies in England have shown that although the aim of community energy projects may be to involve locals, regularly they are reluctant to take control and look to outsiders for guidance and leadership (ibid.). This reluctance to engage can often create barriers to the successful development of SECs and foster an environment where opposition to projects can thrive. The negative phenomenon of Not In My Back Yard (NIMBYism *) and Locally Unwanted Land Use (LULU ${ }^{\dagger}$ ) can easily be taken advantage of by opposition parties when participation of locals is not present. Unfortunately, opposition to renewable energy projects is quantitatively different from support for projects and not just its binary opposite [29]. Often in cases of opposition to renewable energy projects, emotion is used by objectors to gain support while supporters challenge objections with facts [30]. This frequently leads to developers dismissing the

\footnotetext{
* According to Cass and Walker [30] the term NIMBYism is often used to describe the attitude of objectors to LULUs

${ }^{\dagger}$ A LULU is a land use that is useful to society, but the neighbours or community object to it [30]
} 
concerns of communities as emotional, even though some of those concerns highlighted, although emotionally driven, may still count as "valid planning issues" (ibid.).

Furthermore, the insider/outsider distinctions inherent in small communities [29] often means that emotions involved in the planning process of a SEC are more powerful than the logic that it is assumed is applied to the planning process. The Environmental Impact Assessment (EIA) process currently used in planning in Ireland clouds the ideal nature of the planning process as one devoid of emotion and operating solely on logic [30]. The EIA process operates on an "information-deficit model" and regularly gives opposition parties a clear platform to highlight their emotional ideas of a lack of justice and fairness in the project development (ibid.). This emotional aspect often leads to what Janis [31] described as "Groupthink" whereby groups norms that bolster (or harm) morale are created at the expense of critical thinking. One tool for overcoming NIMBYism due to LULU's and the power of Groupthink, is to encourage communities to financially invest in part of the renewable energy project. Warren and McFadyen [13] undertook a comparison of public attitudes towards a community-owned wind-farm on the Isle of Gigha with attitudes towards several developer-owned wind-farms on the adjacent Kintyre peninsula. Their findings showed that the Gigha respondents were consistently more positive about wind power than were the Kintyre residents due to community ownership. Although the Gigha residents were more positive it was a difference of degree of positivity and not completely opposing views. The authors suggest that this may be due to communities gaining positive experiences of a wind-farm situated locally. It has been shown that attitudes to wind-farms have a longitudinal dimension, following a U-shaped curve over time (ibid.). When questioned about wind-farms, communities generally have positive initial responses, but these are often replaced by more negative appraisals when a local wind-farm is proposed. Fortunately, these negative appraisals are generally followed by a return to positive attitudes once the community has experienced the wind-farm. This method of developing communities' understanding of sustainable energy leads to more acceptance of renewable energy developments and better support for projects in the future. Rogers et al. [12] conclude that a clearer framework and more standardised processes with demonstration of renewable energy technologies to raise awareness of community renewable projects are needed. In the next section, the nominated case study is outlined and the methodology used for this initial fieldwork study is described.

\section{METHODS}

Building on the literature and existing SEC frameworks in Ireland, a set of themes were developed for analysis during this initial fieldwork. One framework analysed was the SEAI's "Guidelines for a Sustainable Energy Community" [2]. These guidelines define a five step process to the development of SECs and are outlined in Figure 2 below.

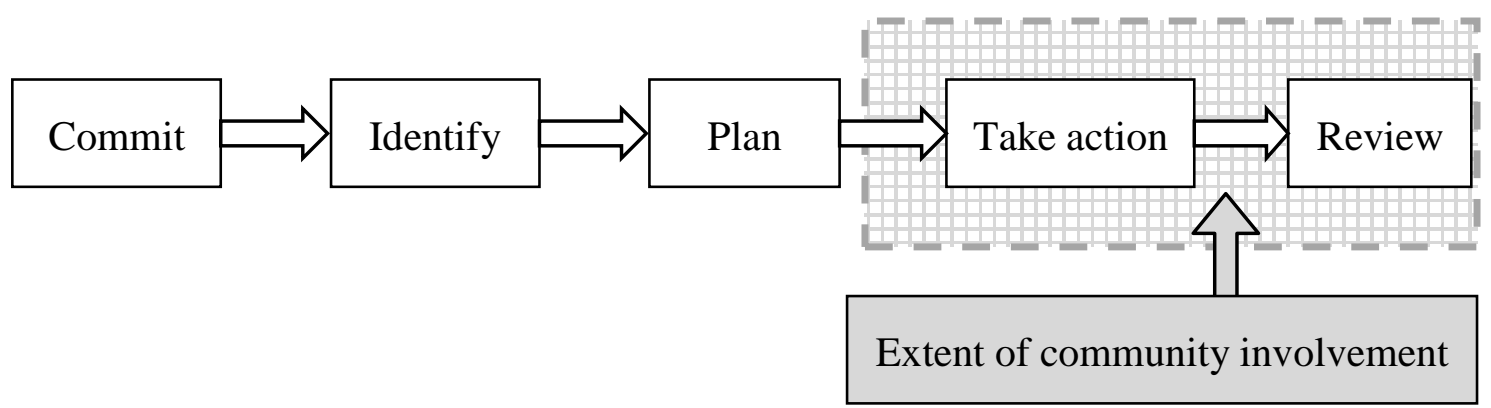

Figure 2. Summary of SEAI’s "Guidelines for a Sustainable Energy Community” [2] 
As Figure 2 illustrates, the SEAI do not recommend community involvement until late in the development process, when the plans have already been finalised and construction of the project is to begin. As a result the level of community involvement was a key theme for analysis in this initial fieldwork study. The primary research in this initial fieldwork involved the undertaking of semi-structured interviews. Building on the literature several themes were identified for analysis in the initial fieldwork studies and are described in Table 1 below.

Table 1. Research themes identified for analysis and the related literature

\begin{tabular}{ccc}
\hline & Themes & References \\
\hline Societal 1 & $\begin{array}{c}\text { Driver and local concept, previous } \\
\text { situation, mission statement and the } \\
\text { local concept }\end{array}$ & {$[28,12,27,30]$} \\
Societal 2 & $\begin{array}{c}\text { Local community involvement } \\
\text { and communication }\end{array}$ & {$[10,13,15,26,29,32,33]$} \\
Societal 3 & Organizational structure & {$[1,3-5,15]$} \\
$\begin{array}{c}\text { Economic \& } \\
\text { political } \\
\text { Miscellaneous }\end{array}$ & Financing, policy and planning & {$[13]$} \\
\hline
\end{tabular}

Questions for the semi-structured interviews were guided by the themes in Table 1 . These interviews were undertaken with project managers from three successful SEC communities, two in Denmark and one in Ireland (Table 2). The study involved extensive semi-structured interviews with the managers of each of the SEC projects and comprehensive site visits of each project. The interviewees who took part in the study were the renewable energy project managers from the following: Marstal community in Aerø Island, Denmark, Samsø Island, Denmark and Cloughjordan eco-village in Ireland.

Table 2. Profile of SECs studied during initial fieldwork

\begin{tabular}{cccc}
\hline & $\begin{array}{c}\text { Marstal, Aerø Island, } \\
\text { Denmark }\end{array}$ & $\begin{array}{c}\text { Samsø Island, } \\
\text { Denmark }\end{array}$ & $\begin{array}{c}\text { Cloughjordan, } \\
\text { Ireland }\end{array}$ \\
\hline Population & 6,669 inhabitants & 3,806 inhabitants & 140 inhabitants \\
Area & $88 \mathrm{~km}^{2}$ & $114 \mathrm{~km}^{2}$ & $0.271 \mathrm{~km}^{2}$ \\
Electricity & Over $80 \%$ self sufficient & $100 \%$ wind power & $\begin{array}{c}\text { From national grid } \\
\text { District heating }\end{array}$ \\
Heating & Over 80\% self sufficient & $\begin{array}{c}75 \% \text { from solar power }+ \\
\text { biomass energy }\end{array}$ & $\begin{array}{c}100 \% \text { biomass }+ \\
\text { solar power } \\
\text { Exporting }\end{array}$ \\
& None & 84 million $\mathrm{kWh}$ & None \\
\hline
\end{tabular}

\section{FINDINGS AND DISCUSSION}

The following section reports on the response of the participants in the study in relation to a range of questions relating to the SEC development methodologies employed within their communities. These questions established the SEC development issues that were of particular importance to the participants. Several key themes emerged in the data and these are outlined in the following sections. 


\section{Societal 1 findings: driver and local concept, previous situation, mission statement} and the local concept

As proposed earlier in this paper, the driver for the development of a SEC can often create prejudices or good will early in the development process. During the interviews, all respondents stated that their projects were financially motivated, giving the community a clearer understanding of the reasons for their SEC development (Table 3). When questioning what community renewable energy means, Rogers et al. [12] analyse what stakeholders feel is distinctive about community renewable energy projects and state that the best type of project is one that is both for and by the people. In each of the communities studied in this initial fieldwork, the community perceived that the SEC was being created in order to bolster their local economy and to reduce their energy costs. This led to increased support and acceptance of the project in the long term.

Table 3. Societal 1 findings: driver and local concept, previous situation, mission statement and the local concept

\begin{tabular}{|c|c|c|c|}
\hline & Marstal, Aerø Island & Samsø Island & Cloughjordan \\
\hline $\begin{array}{c}\text { Driver and local } \\
\text { concept }\end{array}$ & $\begin{array}{l}\text { The high cost of oil } \\
\text { in the 1970's }\end{array}$ & $\begin{array}{l}\text { High level of } \\
\text { unemployment and } \\
\text { economic recovery } \\
\text { was needed }\end{array}$ & $\begin{array}{c}\text { The eco-village } \\
\text { community wished } \\
\text { to create a } \\
\text { sustainable village }\end{array}$ \\
\hline $\begin{array}{c}\text { Current/previous } \\
\text { situation }\end{array}$ & $\begin{array}{c}\text { 1970’s: Completely } \\
\text { dependent on } \\
\text { imported energy }\end{array}$ & $\begin{array}{l}\text { 1990's: Completely } \\
\text { dependent on } \\
\text { imported energy \& } \\
\text { high unemployment }\end{array}$ & $\begin{array}{l}\text { 1990's: Existing } \\
\text { village of } \\
\text { Cloughjordan was } \\
\text { in decline }\end{array}$ \\
\hline Mission statement & $\begin{array}{l}\text { To convert from oil } \\
\text { to renewable energy }\end{array}$ & $\begin{array}{l}\text { To create a } 100 \% \\
\text { renewable energy } \\
\text { island }\end{array}$ & $\begin{array}{l}\text { To create a } \\
\text { sustainable/ } \\
\text { eco-village } \\
\text { community }\end{array}$ \\
\hline Local concept & $\begin{array}{l}\text { Local concept was } \\
\text { not an issue, it was } \\
\text { important that the } \\
\text { cost of heating was } \\
\text { reduced }\end{array}$ & $\begin{array}{l}\text { Community input to } \\
\text { encourage revival of } \\
\text { the local economy } \\
\text { and employment } \\
\text { kept local }\end{array}$ & $\begin{array}{l}\text { Community input to } \\
\text { ensure that the } \\
\text { existing community } \\
\text { accepted the new } \\
\text { residents of the } \\
\text { eco-village }\end{array}$ \\
\hline
\end{tabular}

\section{Societal 2 findings: local community involvement and communication}

Moran's [29] highlighting of the problems experienced during expert-lay interactions indicates that communication methods used by those with expert knowledge and those used by members of the community with lay knowledge are often incompatible. This often leads to feelings of resentment and a perceived lack of fairness. All parties interviewed described how difficulties were experienced in the early stages of the project in relation to expert-lay communication. The solution used in all cases was the use of public meetings (Table 4) where the public can voice their concerns as a group to experts and developers. Lund [33, 34] describes how "Discourse theory" perceives social reality as a linguistic construction and states that different organizations perceive and articulate things differently. As a result, different stakeholders perceive things differently, leading to different ways of approaching the same problem. In this regard, academic institutions can play a lead role in the dissemination of information in an easily understood manner. 
All interviewees had academic involvement during the development process and expressed the benefit of this experience in terms of community interaction.

Table 4. Societal 2 findings: local community involvement and communication

\begin{tabular}{cccc}
\hline & Marstal, Aerø Island & Samsø Island & Cloughjordan \\
\hline & Public meetings, no & Public meetings, & Public meetings, no \\
survey of opinion, & no survey & survey of opinion, \\
Local community & opinions voiced at & of opinion, & people voiced opinions \\
involvement and & meetings, existing & people voiced & at meetings, existing \\
communication & school involved in & opinions at & school was involved \\
& communication & meetings & in communication \\
\hline
\end{tabular}

\section{Societal 3 findings: organizational structure}

Both the Samsø and Cloughjordan project successfully used aspects of the "Bottom-up" approach in the development of their SECs (Table 4). Schweizer-Ries [28] outlines how the "Bottom-up" approach should be the basis for any long-term successful community renewable project. A bottom-up process is defined by individual voluntary support and networking within the community in order to realise a certain energy project. Schweizer-Ries (ibid.) concluded that taking social aspects into account increases successful realization of sustainable energy supply and demand in the future. The attention to the social aspect of both of these projects ensured that they have been successfully integrated into community life in the long-term. A key finding from these interviews was the importance of the "Key influencer" (Table 5). The key influencers within a community are people who already have the attention of the community as a whole. In the case of SECs, the singling out of a single key influencer can often prove to be of benefit and this was very successfully done in Samsø and Cloughjordan. Cass and Walker [30] state that, when dealing with emotion attached to place (as is very common in small communities), it is better to deal with individuals rather than a group. In this situation, it is often better to deal with a single representative for the group, or the key influencer. Barriers exist as both individual (personal barriers) and external barriers (due to participating in a group dynamic) [24]. The use of the key influencer can be used to combat both individual and external barriers through allaying personal fears and challenging barriers suggested by opposing groups. As support for projects is generally more widespread than a wish to participate [12] the importance of the key influencer as a project manager and instigator is clear.

Table 5. Societal 3 findings: organizational structure

\begin{tabular}{|c|c|c|c|}
\hline & Marstal, Aerø Island & Samsø Island & Cloughjordan \\
\hline $\begin{array}{l}\text { Organizational } \\
\text { structure }\end{array}$ & $\begin{array}{l}\text { The organizational } \\
\text { structure was already } \\
\text { defined in the form } \\
\text { of the district heating } \\
\text { co-operative }\end{array}$ & $\begin{array}{l}\text { The master-plan was } \\
\text { sub-divided into } \\
\text { different topics and } \\
\text { these were dealt } \\
\text { with by different } \\
\text { sub-groups }\end{array}$ & $\begin{array}{c}\text { Sustainable } \\
\text { developments limited } \\
\text { co-operative was set } \\
\text { up and this company } \\
\text { was used to organise } \\
\text { the project }\end{array}$ \\
\hline Key influencer & $\begin{array}{l}\text { Manager at Marstal } \\
\text { district heating }\end{array}$ & $\begin{array}{l}\text { Director, energy } \\
\text { co-operative }\end{array}$ & $\begin{array}{l}\text { Project manager of the } \\
\text { eco-village project }\end{array}$ \\
\hline
\end{tabular}




\section{Economic and political findings: financing, policy and planning}

In all SECs studied in this initial fieldwork, the funding models were described as "mixed funding" with funding from the government, the community and bank loans (Table 6). This was described as a very successful method, as community investment led to more community action, participation and support for the development of the project. Warren and McFadyen [13] argue that mixed financing is the best model for a long term successful SEC and this was clear from the findings in this initial fieldwork study.

Table 6. Section 4 findings: financing, policy and planning

\begin{tabular}{|c|c|c|c|}
\hline & Marstal, Aerø Island & Samsø Island & Cloughjordan \\
\hline Financing & $\begin{array}{l}20 \% \text { seed funding from } \\
\text { the Danish Ministry of } \\
\text { Climate, Energy and } \\
\text { Building, profits from } \\
\text { existing district } \\
\text { heating co-operative } \\
\text { and a loan from } \\
\text { Danish green bank } \\
\text { (community gave } \\
\text { guarantee for the loan) }\end{array}$ & $\begin{array}{l}20 \% \text { seed funding from } \\
\text { the Danish Ministry } \\
\text { of Climate, Energy } \\
\text { and Building, energy } \\
\text { project set up on a } \\
\text { co-operative basis and } \\
\text { a loan from the } \\
\text { Danish green bank } \\
\text { (community gave } \\
\text { guarantee for the loan) }\end{array}$ & $\begin{array}{l}\text { The company was set } \\
\text { up on a co-operative } \\
\text { basis, received a loan } \\
\text { from Clann Credo } \\
\text { ethical bank and } \\
\text { EUR 700,000 from the } \\
\text { EU through } \\
\text { the SERVE project }\end{array}$ \\
\hline $\begin{array}{c}\text { Policy and } \\
\text { planning }\end{array}$ & $\begin{array}{l}\text { Given exemptions due } \\
\text { to intervention by the } \\
\text { ministry }\end{array}$ & $\begin{array}{l}\text { Given exemptions due } \\
\text { to intervention by the } \\
\text { ministry }\end{array}$ & $\begin{array}{l}\text { Submitted a proposal } \\
\text { to the county council } \\
\text { to zone the proposed } \\
\text { site for sustainable } \\
\text { development so there } \\
\text { were less planning } \\
\text { application refusals }\end{array}$ \\
\hline
\end{tabular}

\section{Miscellaneous findings: unexpected positives and negatives}

In both the Samsø and Cloughjordan projects (however not in the Aerø project), the interviewees stated that they were pleasantly surprised with the unexpected positives from the development of the SEC. They both had a large increase in tourism and this led to the creation of education and enterprise centres in order to provide sustainable development education (Table 7). Warren and McFadyen's [13] research would indicate that this is commonplace, as tourists in their study stated that the presence of community renewable energy projects did not negatively affect whether they would return or not. The positives that have resulted from these SEC developments are contrary to communities' notions that a SEC project may lead to minor benefits for the community in question while there is large local imposition [30]. However, all communities cited negatives that occurred as a result of the projects including inter-community rivalries and a loss of privacy for the residents.

As can be seen from the findings in this research, each of the SEC communities studied experienced similar barriers and enablers in the development of their SECs. The findings in this research indicate that although each of the SECs studied did not have any specific implementation framework developed for their projects, many of the successful tools and methodologies used across all communities were similar. These similarities and lessons are discussed in the conclusion following this section. 
Table 7. Miscellaneous findings: unexpected positives and negatives

\begin{tabular}{|c|c|c|c|}
\hline & Marstal, Aerø Island & Samsø Island & Cloughjordan \\
\hline $\begin{array}{l}\text { Unexpected } \\
\text { positives }\end{array}$ & None cited & $\begin{array}{l}\text { Increase in tourism, } \\
\text { creation of an } \\
\text { education centre, } \\
\text { increased pride in the } \\
\text { islanders and increased } \\
\text { employment }\end{array}$ & $\begin{array}{l}\text { Increase in tourism } \\
\text { numbers, the creation } \\
\text { of an enterprise centre } \\
\text { and a better quality of } \\
\text { life for the residents }\end{array}$ \\
\hline $\begin{array}{l}\text { Unexpected } \\
\text { drawbacks }\end{array}$ & $\begin{array}{l}\text { Consumers of the heat } \\
\text { are still not aware } \\
\text { where energy comes } \\
\text { from as the district } \\
\text { heating company just } \\
\text { delivers heat at the } \\
\text { touch of a button }\end{array}$ & $\begin{array}{l}\text { Complexity of the } \\
\text { project, bitterness has } \\
\text { evolved between some } \\
\text { islanders in relation to } \\
\text { certain aspects of the } \\
\text { project }\end{array}$ & $\begin{array}{l}\text { Privacy of the residents } \\
\text { is compromised by the } \\
\text { constant flow of visitors } \\
\text { to the eco-village, the } \\
\text { residents had to move } \\
\text { from their original } \\
\text { homes to the eco-village }\end{array}$ \\
\hline
\end{tabular}

\section{CONCLUSION}

The semi-structured interview methodology used in this research was chosen in order to gather knowledge on the barriers and enablers to SEC development in two communities in Denmark and one in Ireland. There were similarities in the findings across all communities analysed and the major findings are outlined below:

- The driver for the project needs to be shared with the community and align itself with the wants and needs of the community involved;

- Public meetings are the best method for communicating with communities;

- It is important to use any existing organizational structures or networks where possible;

- The "Key influencer" is often the most important person in the development process and a determined proactive key influencer can mean the success or failure of a SEC project;

- Using mixed methods of financing for SEC projects was cited by all interviewees as the most successful method of financing projects. These should involve funding from government, community investment and bank loans;

- It is important to be aware that unexpected drawbacks to the project may occur and to make the community aware that these may happen as early in the project development as possible.

\section{FUTURE WORK}

There is a need for future studies in Europe in terms of developing a framework for the introduction of SECs. The level of community involvement recommended in the SEAI's "Guidelines for a Sustainable Energy Community" [2] are significantly later in the SEC development process than in the successful methodologies used by both Samsø and Cloughjordan SECs (Figure 3).

The findings from this initial fieldwork study would suggest that for a framework for the development of SECs to be successful, community involvement needs to play a larger role earlier in the process. Future work will involve the investigation of methodologies for achieving this. Exploring the following as future research strategies can facilitate the attainment of this goal: 
- Assessing a strategy for embedding community involvement into SEC development process;

- Assessing the effect that the participation of communities and the key influencers have on the success or failure of SEC development methodologies.

SEAI's Guidelines for a Sustainable Energy Community

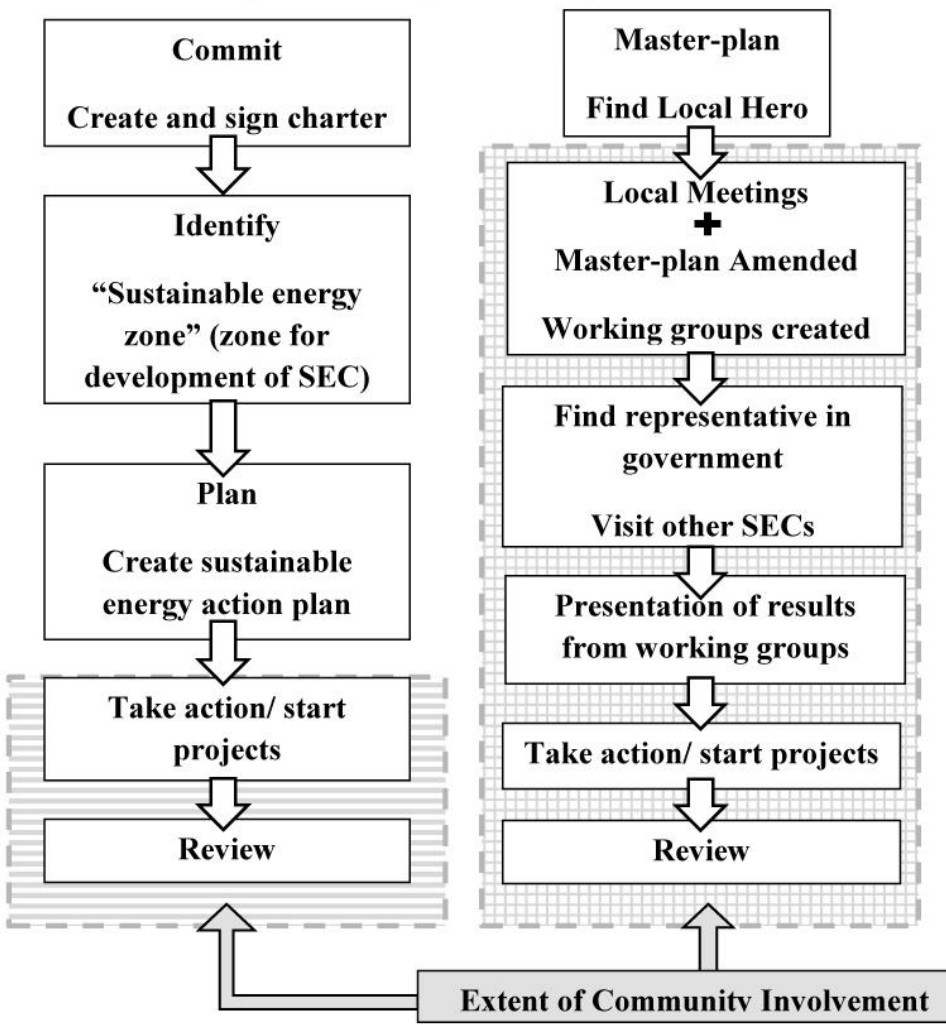

SEC development methodology implemented in Cloughjordan

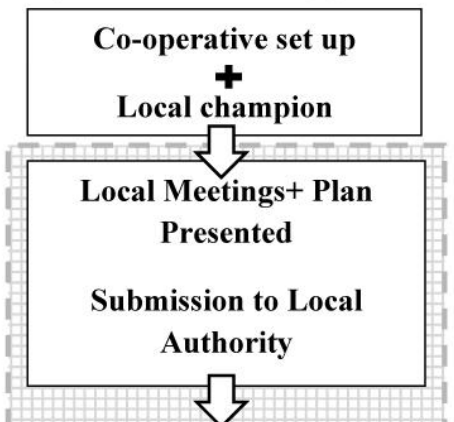

Presentation of plan to community + schools

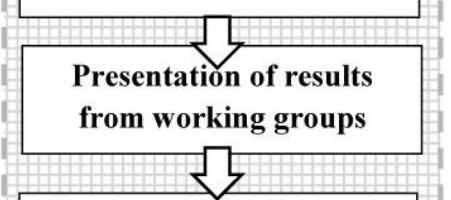

Take action/ start projects \々 Review

Figure 3. Comparison of SEAI's "Guidelines for a Sustainable Energy Community" (ibid.) and the findings from this study of methodologies used in Samsø and Cloughjordan SECs

\section{LIMITATIONS TO THIS STUDY}

Although only three semi-structured interviews and site-visits have been undertaken in this initial study, these were comprehensive in nature. The knowledge garnered from this study has led to initial themes being identified for future work, which will be built upon over the coming years.

\section{AKNOWLEDGEMENT}

Thanks to the interviewees for taking part in this research. This research could not have been completed without their patience and cooperation. The project was funded by GMIT President's Forty Year Scholarship.

\section{REFERENCES}

1. Crow, G. and Mah, A., Conceptualisations and Meanings of 'Community': the Theory and Operationalization of a Contested Concept, 2011, https://scholar.google.com/ scholar?hl=en\&q=Conceptualisations+and+meanings + of $+\% \mathrm{E} 2 \% 80 \% 9$ Ccommunity $\% \mathrm{E} 2 \% 80 \% 9 \mathrm{D} \% 3 \mathrm{~A}+$ the+theory+and+operationalisation+of $+\mathrm{a}+$ contested+concept + $\& b t n G=\& a s \_s d t=1 \% 2 C 5 \& a s \_s d t p=$, [Accessed: 01-March-2016] 
2. O'Hora, A., Guidelines for a Sustainable Energy Community, 2010, http://www.seai.ie/SEC/Toolkit/Guidelines_for_a_Sustainable_Energy_Community .pdf, [Accessed: 10-August-2014]

3. EC, CONCERTO: A Cities' Guide to a Sustainable Built Environment (E. Communities, ed.), 2010: Belgium.

4. ICLEI, ICLEI Europe: Information \& Communication, 2016, http://www.iclei-europe.org/products-activities/information-communication/, [Accessed: 10-August-2014]

5. energy_cities_EU, Covenant of 2016, http://www.covenantofmayors.eu/index_en.html, [Accessed: 10-August-2014]

6. Jørgensen, P. J., et al., Samsø a Renewable Energy Island: 10 Years of Development and Evaluation, A Description and Evaluation of the Last 10 Years Work on Samsø Towards 100\% Renewable Energy (Energiakademi, S., ed.), Denmark: Chronografisk, 2007.

7. Müller, M. O., et al., Energy Autarky: A Conceptual Framework for Sustainable Regional Development, Energy Policy, Vol. 39, No. 10, pp 5800-5810, 2011, http://dx.doi.org/10.1016/j.enpol.2011.04.019

8. Winston, N., Sustainable Housing: A Case Study of the Cloughjordan Eco-village, Advances in Ecopolitics (Davies, A., ed.), Emerald Group Publ. Limited, 2012.

9. Walker, G., What are the Barriers and Incentives for Community-owned Means of Energy Production and Use?, Energy Policy, Vol. 36, No. 12, pp 4401-4405, 2008, http://dx.doi.org/10.1016/j.enpol.2008.09.032

10. Blake, J., Overcoming the 'Value-Action Gap' in Environmental Policy: Tensions between National Policy and Local Experience, Local Environment, Vol. 4, No. 3, pp 257, 1999, http://dx.doi.org/10.1080/13549839908725599

11. Büscher, C. and Sumpf, P., "Trust" and "Confidence" as Socio-technical Problems in the Transformation of Energy Systems, Energy, Sustainability and Society, Vol. 5, No. 1, pp 1-13, 2015, http://dx.doi.org/10.1186/s13705-015-0063-7

12. Rogers, J. C., et al., Public Perceptions of Opportunities for Community-based Renewable Energy Projects, Energy Policy, Vol. 36, No. 11, pp 4217-4226, 2008, http://dx.doi.org/10.1016/j.enpol.2008.07.028

13. Warren, C. R. and McFadyen, M., Does Community Ownership Affect Public Attitudes to Wind Energy? A Case Study from South-west Scotland, Land Use Policy, Vol. 27, No. 2, pp 204-213, 2010, http://dx.doi.org/10.1016/j.landusepol.2008.12.010

14. EC, Energy 2020, A Strategy for Competitive, Sustainable and Secure Energy, 2010.

15. Mendonça, M., Lacey, S. and Hvelplund, F., Stability, Participation and Transparency in Renewable Energy Policy: Lessons from Denmark and the United States, Policy and Society, Vol. 27, No. 4, pp 379-398, 2009, http://dx.doi.org/10.1016/j.polsoc.2009.01.007

16. The Danish Government, The Danish Climate Policy Plan: Towards a Low Carbon Society, the Ministry of Climate, Energy and Building, 2013.

17. DoCEaNR, National Renewable Energy Action Plan Ireland, in submitted under Article 4 of Directive 2009/28/EC, Dublin, Ireland, 2012.

18. SEAI, The SEC Programme - Leading Ireland to a Sustainable Energy Future, Sustainable Energy Communities Programme, 2011, http://www.seai.ie/SEC/ SEC_Programme/SEC_Programme_Overview/, [Accessed:14-October-2013]

19. Howley, M., et al., Energy in Ireland 1990-2014 (S.E.A.o., ed.), Ireland, Dublin, 2015.

20. NESC, Wind Energy in Ireland: Building Community Engagement and Social Support, National Environmental and Social Development Office, 2014. 
21. DoCEaNR, Ireland's Transition to a Low Carbon Energy Future 2015 - 2030, Department of Communications, Energy and Natural Resources: Dublin, Ireland, 2015.

22. DoCaMNR, Delivering a Sustainable Energy Future for Ireland, C.a.N.R. Department of Marine, Editor, Department of Marine, Communications and Natural Resources: Dublin, Ireland, 68 p, 2007.

23. Østergaard, P. A., et al., A Renewable Energy Scenario for Aalborg Municipality based on Low-temperature Geothermal Heat, Wind Power and Biomass, Energy, Vol. 35, No. 12, pp 4892-4901, 2010, http://dx.doi.org/10.1016/j.energy.2010.08.041

24. Clark Ii, W. W. and Eisenberg, L., Agile Sustainable Communities: On-site Renewable Energy Generation, Utilities Policy, Vol. 16, No. 4, pp 262-274, 2008, http://dx.doi.org/10.1016/j.jup.2008.01.009

25. Lund, H., Renewable Energy Strategies for Sustainable Development, Energy, Vol. 32, No. 6, pp 912-919, 2007, http://dx.doi.org/10.1016/j.energy.2006.10.017

26. Walker, G. and Devine-Wright, P., Community Renewable Energy: What Should it Mean?, Energy Policy, Vol. 36, No. 2, pp 497-500, 2008, http://dx.doi.org/10.1016/j.enpol.2007.10.019

27. Rae, C. and Bradley, F., Energy Autonomy in Sustainable Communities - A Review of Key Issues, Renewable and Sustainable Energy Reviews, Vol. 16, No. 9, pp 6497-6506, 2012, http://dx.doi.org/10.1016/j.rser.2012.08.002

28. Schweizer-Ries, P., Energy Sustainable Communities: Environmental Psychological Investigations, Energy Policy, Vol. 36, No. 11, pp 4126-4135, 2008, http://dx.doi.org/10.1016/j.enpol.2008.06.021

29. Moran, L., Knowing Nature: Lay Knowledge, Concepts of Sustainability and Expert-lay Participation in Connemara, School of Political Science and Sociology, National University of Ireland, Galway: Galway, Ireland, 2011.

30. Cass, N. and Walker, G., Emotion and Rationality: The Characterisation and Evaluation of Opposition to Renewable Energy Projects, Emotion, Space and Society, Vol. 2, No. 1, pp 62-69, 2009, http://dx.doi.org/10.1016/j.emospa.2009.05.006

31. Janis, I. L., Leadership: Understanding the Dynamics of Power and Influence in Organizations (Vecchio, R. P., ed.), University of Notre Dame Press: Notre Dame, IN, US, pp 163-176, 1997.

32. Wüstenhagen, R., Wolsink, M. and Bürer, M. J., Social Acceptance of Renewable Energy Innovation: An Introduction to the Concept, Energy Policy, Vol. 35, No. 5, pp 2683-2691, 2007, http://dx.doi.org/10.1016/j.enpol.2006.12.001

33. Lund, H., Renewable Energy Systems: The Choice and Modeling of 100\% Renewable Solutions, Amsterdam, London: Elsevier, 2010.

34. Lund, H., Renewable Energy Systems: A Smart Energy Systems Approach to the Choice and Modeling of 100\% Renewable Solutions, Academic Press, 2014. 